\title{
PENGARUH KEPEMIMPINAN ISLAMI DAN BUDAYA ORGANISASI ISLAMI TERHADAP MOTIVASI KERJA ISLAMI PADA UMKM KULIT DI MAGETAN
}

\author{
Rezy Aziz \\ Mahasiwa Program Studi S1 Ekonomi Islam - Fakultas Ekonomi dan Bisnis - Universitas \\ Airlangga \\ Atina Shofawati, SE., M.Si. \\ Departemen Ekonomi Syariah - Fakultas Ekonomi dan Bisnis - Universitas Airlangga \\ Email: atinashofawati@yahoo.com
}

\begin{abstract}
The purpose of this research is to know the effect of islamic leadership and islamic organization culture in variable through islamic work motivation to SMEs leather in Magetan.

This research uses questionnaires in primary data collected and the method used is quantitative descriptive by using two independent variables islamic leadership and islamic organization culture and a dependent variable islamic work motivation. Research sampling is the employee of SMEs leather in Magetan industry area in east java, it was 110 people. Sampling collected takes in proportioned stratified random sampling because each SMEs leather will be taken a random sampling. Data analysis technique used is multiple linear regression analysis by using $F$ and $T$ treatment as hypothesis

The results showed that simultaneous and partial Islamic leadership and Islamic organizational culture influence significant on Islamic work motivation.
\end{abstract}

Keywords: Islamic leadership, organizational culture Islamic, Islamic work motivation

\section{PENDAHULUAN}

Karyawan merupakan salah satu sumber daya perusahaan yang penting dalam menunjang perputaran suatu bisnis. Karyawan yang bekerja untuk perusahaan memiliki berbagai kemampuan mulai dari bakat, tenaga, dan kreativitas. Di lain pihak, karyawan juga membutuhkan perusahaan untuk memenuhi berbagai macam kebutuhan hidupnya mulai kebutuhan makan, tempat tinggal, dan kesejahteraan lainnya. Hal inilah yang menjadi faktor pendorong (motivasi) karyawan untuk bekerja dan membantu bisnis perusahaan (Suryati, 2010).
Motivasi kerja merupakan sebuah dorongan kehendak yang dapat mempengaruhi perilaku tenaga kerja untuk dapat meningkatkan produktivitas kerja. Hal ini berkaitan dengan keyakinan karyawan bahwa semakin banyak kontribusi yang diberikan maka semakin banyak pula manfaat yang akan diperoleh seperti vang, liburan, atau lainIain (Mulianto, 2006). Begitupun dalam praktek kehidupan secara Islami yang mana motivasi yang memiliki etos kerja yang tinggi adalah seperti firman Allah SWT dalam surat QS At-Taubah (9:105). 


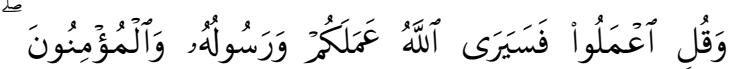

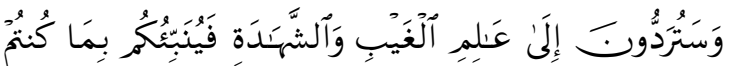
تَعَمَلُونَنَ

Wa quli'malū fa sayarallāhu 'amalakum wa rasūluhū wal mu'minūn(a), wa saturaddūna ilā 'ālimil gaibi wasy syahādati fayunabbi'ukum bimā kuntum ta'malūn(a).

Artinya: "Dan Katakanlah: "Bekerjalah kamu, Maka Allah dan Rasul-Nya serta orang-orang mukmin akan melihat pekerjaanmu itu, dan kamu akan dikembalikan kepada (Allah) yang mengetahui akan yang ghaib dan yang nyata, lalu diberitakan-Nya kepada kamu apa yang telah kamu kerjakan." (QS AtTaubah, 9:105)

Setiap pimpinan perusahaan hendaknya memahami kebutuhankebutuhan karyawan dalam usaha meningkatkan motivasi kerja karyawannya dengan memenuhi semua kebutuhan karyawan tersebut sesuai dengan kontribusi karyawannya. Salah satu yang dapat mempengaruhi motivasi kerja karyawannya adalah keberadaan pimpinan yang dapat memimpin karyawan dengan baik. Kepemimpinan yang baik adalah bagaimana cara memperlakukan orang lain, dan bagaimana kemampuan mengilhami orang yang dipimpinnya (Zahro, 2005).

Pemimpin dalam mengelola perusahaan mempunyai gaya kepemimpinan yang bermacam-macam, salah satunya adalah gaya kepemimpinan Islami. Menurut Rizqi (2010) dalam penelitiannya menyatakan bahwa kepemimpinan Islami merupakan kepemimpinan yang berdasarkan pada Al-Qur'an dan Hadits. Prinsip-prinsip kepemimpinan Islami yang dinyatakan sebagai seorang pekerja yang ideal karena ilmunya bersumber dari Al-Qur'an dan Hadits.

Kepemimpinan yang Islami mencakup beberapa hal, yaitu syaratsyarat kepemimpinan Islami, karakteristik kepemimpinan Islami, dan ciri-ciri kepemimpinan Islami. Syarat-syarat kepemimpinan Islami memiliki akidah yang benar, memiliki ilmu pengetahuan dan wawasan luas, memiliki akhlak yang mulia, dan memiliki kecakapan manajerial. Berikut firman Allah SWT dalam surat QS. Al-Anbiya (21:73)

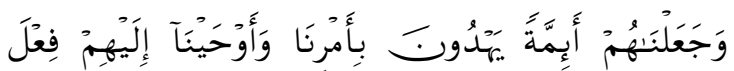

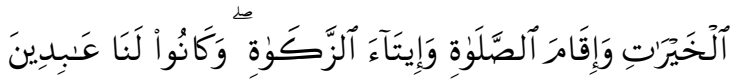

Wa ja'alnāhum a'immatay yahdūna bi amrinā wa auhainā ilaihim fi'lal khairāti wa iqāmas salāti wa itā'az zakāh(ti), wa kānū lanā 'àbidìn(a).

Artinya : "Kami telah menjadikan mereka itu sebagai pemimpin-pemimpin yang memberi petunjuk dengan perintah Kami dan telah Kami wahyukan kepada, mereka mengerjakan kebajikan, mendirikan sembahyang, menunaikan zakat, dan hanya kepada kamilah mereka selalu menyembah." (QS. AlAnbiya (21:73) 
(Hakim, 2012) menjelaskan bahwa saat ini begitu banyak perusahaan yang bersaing untuk mendominasi sumber daya manusia. Para perusahaan tersebut memanfaatkan karyawan secara berlebihan tanpa memperhatikan kebutuhan karyawan. Hal ini karena perusahaan belum menerapkan aturan Islam secara total. Oleh karena itu penting sekali bagi perusahaan untuk menerapkan kepemimpinan yang Islami dan organisasi yang bernafaskan Islam, sehingga bisa memberikan motivasi spiritual Islam kepada karyawan. Sebagaimana dalam mengerjakan tuntutan syariat Islam dalam segala aspek kehidupan, maka terciptanya suatu kepemimpianan yang disebutkan tersebut memungkinkan seorang Muslim dalam menyangkut kehidupan diri sendiri maupun suatu kaum sehingga mampu menjaga hubungannya secara vertikal (kepada Allah SWT) dan horizontal (umatnya), berikut firman Allah SWT dalam surat QS. Al-Imran (3:103):

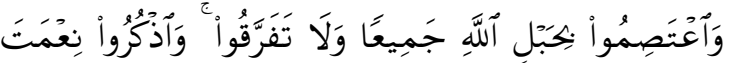

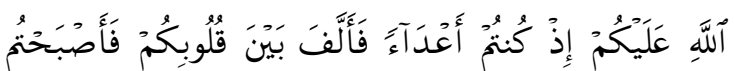

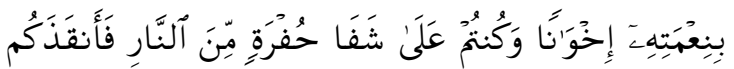

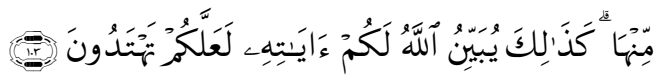
Wa'tașimū bi hablillāhi jamīaw wa lā tafarraqū, ważkurū ni'matallāhi 'alaikum iż kuntum a'dā'an fa allafa baina qulūbikum fa așhbahtum bi ni'matihī ikhwānā(n), wa kuntum 'alā syafā hufratim minan nāri fa anqażakum minhā, każālika yubayyinullāhu lakum āyātihì la'allakum tahtadūn(a).

Artinya : "Dan berpeganglah kamu semuanya kepada tali (agama) Allah, dan janganlah kamu bercerai berai, dan ingatlah akan nikmat Allah kepadamu ketika kamu dahulu (masa Jahiliyah) bermusuh-musuhan, Maka Allah mempersatukan hatimu, lalu menjadilah kamu karena nikmat Allah, orang-orang yang bersaudara; dan kamu telah berada di tepi jurang neraka, lalu Allah menyelamatkan kamu dari padanya. Demikianlah Allah menerangkan ayatayat-Nya kepadamu, agar kamu mendapat petunjuk." QS. Al-Imran (3:103)

Hasil penelitian tersebut sejalan dengan penelitian yang dilakukan oleh (Ahmad, 2009), bahwa dalam perspektif Islam, kepemimpinan adalah kepercayaan atau amanah yang melibatkan kontrak psikologis antara pemimpin dan pengikutnya melakukan perbuatan baik. Dengan demikian, seorang pemimpin harus memiliki karakter moral yang kuat dikembangkan melalui empat tahap perkembangan spiritual, yaitu Islam, Iman, Taqwa, dan Ihsan. Islam memandang bahwa kepemimpinan akan dipertanggungjawabkan di hadapan Allah SWT, berikut firmannya dalam surat QS. Al-Mu'minuun (23:8) yang berbunyi:

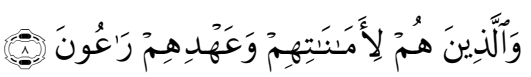

Wal lażina hum li amānātihim wa 'ahdihim rā'ūn(a). 
Artinya : "Dan orang-orang yang memelihara amanat-amanat (yang dipikulnya) dan janjinya." QS. AlMu'minuun (23:8).

Sementara itu ketika ada timbul kelalaian, secara sadar karyawan akan merasa bertanggung jawab atas kelalaiannya karena ada rasa takut kepada Allah. Dalam hal ini tentu kedisiplinan kerja berperan sebagai dorongan kepada karyawan untuk berbuat dan melakukan segala kegiatan sesuai dengan norma-norma ataupun peraturan yang sesuai dengan kaidah yang diatur dalam ketetapan Islam. Dengan adanya kedisiplinan setiap karyawan maka akan tercipta suatu keadaan tertib melaksanaan pekerjaan dan kewajibannya dengan hati ikhlas dan Qanaah. Hal ini tentu akan menciptakan hubungan baik antara pimpinan dan karyawan karena suasana yang dibagun dalam perusahaan adalah kesadaran (Hakim, 2012).

Pada penelitian ini, peneliti menggunakan UMKM yang bergerak di bidang pengolahan kulit sebagai obyek penelitian. UMKM kerajinan kulit ini di pilih sebagai obyek penelitian karena dalam prakteknya ada beberapa hal-hal menarik sekitar usaha kerajinan tersebut. Daerah Magetan dipilih sebagai daerah penelitian karena dalam bidang bisnis, Magetan memiliki kawasan industri yaitu kerajinan kulit yang banyak menghasilkan berbagai macam barang mulai dari sarung tangan, ikat pinggang, sandal, sepatu, tas dan lainnya. Hal ini di dukung oleh industri pengolahan kulit yang terpusat di Lingkungan Indutri Kecil (LIK).

Dalam meningkatkan motivasi karyawan diperlukan seseorang pemimpin yang mampu mengarahkan karyawan dengan baik, yang berdasarkan syari'ah Islam. Alasan inilah yang melatarbelakangi penulis untuk mengambil topik penelitian mengenai pengaruh kepemimpinan Islami terhadap motivasi kerja karyawan Islam.

Industri kerajinan kulit di Magetan telah ada sejak lama dan mengalami pasang surut. Pada tahun 1950-1960 merupakan masa keemasannya dari industri kulit tersebut termasuk di desa Mojopurno. Karena banyaknya pengusaha kulit di desa Mojopurno yang sukses maka pada tahun 1960 beberapa dari pengusaha kulit tersebut berdiskusi untuk membuat suatu lembaga guna mengayomi usaha penyamakan dan pengembangan ajaran agama Islam baik untuk para pengusaha sendiri, maupun untuk para karyawan, serta untuk anak cucu para pengusaha dan karyawan dari industri penyamakan kulit di Magetan.

Sebagai salah satu langkah untuk mewujudkan hasil diskusi tersebut, pada tahun yang sama didirikanlah sebuah Madrasah Diniah untuk menyekolahkan putra putri para pengusaha maupun karyawan penyamakan kulit. Dengan semakin berkembangnya usaha kulit yang ada di Desa Mojopurno, pada tahun 1975 para pengusaha tersebut akhirnya dapat membangun sebuah Madrasah 
Tsanawiah. Sehingga sarana pendidikan menjadi lebih baik dan lengkap.

Dalam proses pembenahan sarana pendidikan untuk pengusaha dan karyawan, pada tahun 1985 dibangun sebuah Madrasah Aliyah di sana. Dengan peningkatan sarana pendidikan ini, di dapatkan bahwa industri penyamakan kulit di Desa Mojopurno terus mengalami perkembangan dan peningkatan. Salah satu bukti semakin berkembangnya usaha penyamakan kulit ialah banyaknya orang yang dulunya bekerja sebagai karyawan, saat ini berhasil menjadi salah satu pengusaha penyamakan kulit.

Tertanamnya budaya Islam yang telah mengakar di daerah Magetan menjadikan spirit karyawan semakin tinggi dalam bekerja. Hal ini disebabkan banyak pengusaha penyamakan kulit telah mampu menunaikan ibadah haji dan umroh, sehingga memicu para pengusaha lain maupun karyawan yang belum bisa menunaikan ibadah haji maupun umroh untuk bekerja lebih giat lagi. Sebagai daerah yang kental akan nuansa Islami, lingkungan industri kecil penyamakan kulit juga memiliki berbagai bentuk kegiatan yang bernuansa Islami. Kegiatan tersebut antara lain; 1) pengajian umum yang diselenggarakan setiap sabtu pagi di masjid lingkungan industri kecil, 2) pengajian bulanan (khataman Qur'an di Madrasah yang diikuti oleh pengusaha, karyawan, serta masyarakat sekitar), 4) pengusaha mengangkat anak yatim atau kurang mampu untuk dijadikan anak asuh dan disekolahkan di Madrasah dan pulang sekolahnya anak-anak tersebut diajari untuk memproses penyamakan kulit.

Berdasarkan latar belakang tersebut, maka penelitian ini akan mengambil judul "Pengaruh kepemimpinan Islami dan budaya organisasi Islami terhadap motivasi kerja Islami pada UMKM kulit di Magetan".

\section{Rumusan Masalah}

Berdasarkan latar belakang di atas maka dapat diambil rumusan masalah adalah: "Apakah kepemimpinan Islami dan budaya organisasi Islami berpengaruh terhadap motivasi kerja Islami pada UMKM kulit di Magetan" ?

\section{Tujuan Penelitian}

Tujuan penelitian ini adalah: "Untuk mengetahui pengaruh kepemimpinan Islami dan budaya organisasi Islami terhadap motivasi kerja Islami pada UMKM kulit di Magetan.

\section{LANDASAN TEORI}

\section{Kepemimpinan}

Kepemimpinan

(leadership) adalah kemampuan untuk mempengaruhi suatu kelompok ke arah suatu tujuan. Kepemimpinan adalah pengaruh antara pribadi yang diarahkan melalui proses komunikasi ke arah pencapaian tertentu (Robbins, 2006). Senada Friska (2004), bahwa kepemimpinan adalah kekuasaan untuk mempengaruhi seseorang, baik dalam mengerjakan sesuatu atau tidak mengerjakan sesuatu. Pemimpin memadukan kebutuhan dari 
bawahannya dengan kebutuhan organisasi dan kebutuhan masyarakat secara keseluruhannya.

\section{Kepemimpinan Islami}

Kepemimpinan atau leadership dalam bahasa Arab disebut dengan khilafah. Kepemimpinan Islam dalam suatu organisasi diperoleh dari sumbersumber Islami yang kemudian diaplikasikan dalam organisasi dengan kepercayaan dan praktek secara Islami berdasarkan Al-Qur'an dan Sunnah (Ahmad, 2011). Prinsip kepemimpinan berdasarkan Al-Qur'an dan Sunnah bukanlah suatu hal yang terbilang baru di lapisan masyrakat. Namun, hal tersebut lebih menekankan kepada kita tentang kembalinya pemikiran hati dan nurani yang bersumber pada Al-Qur'an dan Sunnah serta menerapkannya pada seluruh aspek kehidupan (Hossain dalam Ahmad, 2011).

Pola kepemimpinan Rasullullah Muhammad SAW membentuk sebuah paradigma kepemimpinan. Menurut Tasmara (2006), paradigma kepemimpinan dalam Islam terdiri dari dua bagian, yaitu:

a. Paradigma legal formalistik, yaitu kepemimpinan yang dilakukan oleh orang Muslim, azas-azas yang digunakan juga Islam, simbol-simbol yang dipakai juga mencerminkan Islam. Hal ini terlepas apakah caranya dalam memimpin itu berpegang pada prinsip-prinsip bila dasar kelslaman atau tidak. b. Paradigma esensial substansial, yaitu kepemimpinan yang didalamnya terdapat nilai-nilai Islam yang dipraktekkan dalam mengelola sebuah organisasi, seperti menjaga sifat amanah, kejujuran, keadilan, musyawarah, keihlasan, tanggung jawab, dan lain sebagainya. Hal ini dilakukan tanpa melihat apakah orang-orang yang terlibat di dalamnya Muslim atau non Muslim.

\section{Budaya Organisasi}

Organisasi merupakan suatu perantara untuk mencapai tujuan bersama. Dalam suatu organisasi terdapat berbagai macam karakter berbeda dari individu-individu yang ada didalamnya. Keaneka ragaman tersebut harus diolah dengan baik agar dapat menjadi suatu kesatuan dan keselarasan. Sobirin (2007:5) mengemukakan bahwa organisasi merupakan suatu sistem sosial yang memiliki pola kerja yang teratur yang didalamnya dikelolah oleh beberapa manusia demi mencapai tujuan bersama.

Robbins (2006) menyatakan bahwa organisasi adalah sautu kesatuan sosial yang dikoordinasikan secara sadar dengan sebuah batasan yang dapat diidentifikasi untuk mencapai tujuan bersama. Agar dapat mencapai tujuan yang ditetapkan, maka suatu organisasi harus dijalankan oleh pemimpin beserta staf dan karyawan.

Dari kedua definisi organisasi tersebut dapat ditarik suatu kesimpulan bahwa organisasi merupakan suatu 
struktur atau kesatuan sosial dimana orang-orang didalamnya mengikuti pola kerja yang telah diatur serta dikoordinasikan secara formal untuk mencapai target atau tujuan bersama.

\section{Budaya Organisasi Islam}

Budaya organisasi Islam merupakan sebuah nilai yang diambil dan dikembangkan untuk diterapkan dalam kehidupan sehari-hari atau kegiatan dengan menggunakan nilai-nilai Islam yang sesuai dengan pedoman Islam yaitu Alqu'an dan Hadits (Hakim, 2012).

Budaya organisasi Islam yang dilakukan akan menimbulkan perspektif Islam di dalam budaya tersebut agar memberikan dasar atau pijakan yang dapat menjadikan bentuk serta cara yang perlu diselenggarakan secara kolektif melalui suatu organisasi, menjadikan servan atau ajakan kepada seseorang (pemimpin) untuk mengikuti ajaran dan aturan yang ada di dalamnya, seperti firman Allah SWT dalam surat Q.S Ali' Imran (3:1 10):

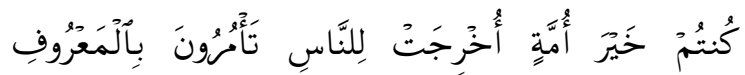

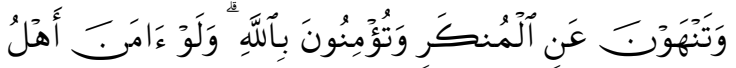

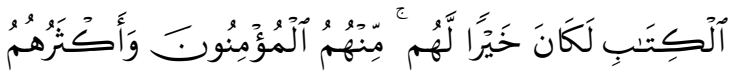
ألْفَسِقُونَ

Kuntum khaira ummatin ukhrijat linnāsi ta'murūna bil ma'rūfi wa tanhauna 'anil munkari wa tu'minūna billāh(i), wa lau āmana ahlul kitābi lakāna khairal lahum, minhumul mu'minūna wa'akṡaruhumul fāsiqūn(a).
Artinya: "Kamu adalah umat yang terbaik yang dilahirkan untuk manusia, menyuruh kepada yang ma'ruf, dan mencegah dari yang munkar, dan beriman kepada Allah. Sekiranya ahli kitab beriman, tentulah itu lebih baik bagi mereka, di antara mereka ada yang beriman, dan kebanyakan mereka adalah orang-orang yang fasik." (Q.S Ali' Imran 3:110).

Menurut Institut Manajemen Masjid (2012) yang dikutip dari immasjid.com menyatakan bahwa suatu organisasi Islam adalah lembaga atau organisasi yang berda'wah secara Islam dalam menyelenggarakan aktivitas da'wahnya yang bersumber dari Al-Quran dan Sunnah Rasulullah Muhammad SAW dengan strategi, program, aktivitas dan pengembangan yang berwawasan Islami yakni yang memiliki Asas, Tujuan, Visi, Misi, dan Nilai-Nilai.

\section{Motivasi Kerja}

Motivasi berasal dari bahasa Latin movere, yang berati dorongan, sebab atau alasan seseorang melakukan sesuatu. Dengan demikian motivasi berarti suatu kondisi yang mendorong atau menjadi sebab seseorang melakukan suatu perbuatan atau kegiatan (Nawawi, 2003).

Usaha yang dilakukan oleh manusia untuk memenuhi keinginan dan kebutuhannya, namun agar keinginan dan kebutuhannya dapat terpenuhi tidaklah mudah didapatkan apabila tanpa usaha yang maksimal. Mengingat kebutuhan orang yang satu dengan yang 
lain berbeda-beda, tentunya cara untuk memperolehnya akan berbeda pula. Dalam memenuhi kebutuhannya seseorang akan berperilaku sesuai dengan dorongan yang dimiliki dan apa yang mendasari perilakunya, untuk itu dapat dikatakan bahwa dalam diri seseorang ada kekuatan yang mengarah pada kebutuhannya disebut dengan motivasi (Koesmono, 2010).

\section{Tujuan Motivasi}

Menurut Singodimedjo (2002) pada hakekatnya tujuan pemberian motivasi kepada para karyawan adalah untuk:

1. Mengubah perilaku karyawan sesuai dengan keinginan perusahaan

2. Meningkatkan gairah dan semangat kerja

3. Meningkatkan disiplin kerja

4. Meningkatkan prestasi kerja

5. Mempertinggi moral kerja karyawan

6. Meningkatkan rasa tanggung jawab

7. Meningkatkan produktivitas dan efisiensi

8. Menumbuhkan loyalitas karyawan pada perusahaan.

\section{Motivasi kerja Islami}

Teori motivasi telah berusaha untuk menjawab masalah motivasi dari berbagai sudut pandang, masing-masing menyajikan konsep yang berbeda dari istilah tersebut. Namun, semua tampaknya membahas suatu fakta yang sama, bahwa motivasi merupakan aspek yang membangkitkan, mengarahkan, dan mengintegrasikan perilaku seseorang. Hal tersebut diketahui tidak dengan melakukan pengamatan secara langsung, tetapi pernyataan tersebut diperoleh dari kesimpulan atas perilaku individu (Ahmad, 2007:194).

Dalam memahami motivasi kerja dalam Islam, terlebih dahulu perlu mengetahui tentang fungsi serta kedudukan bekerja. Bekerja atau mencari nafkah dalam Islam merupakan suatu kewajiban serta ibadah yang memiliki tujuan untuk memenuhi kebutuhan dalam kehidupan sehari-hari (Pramandhika, 2011).

Menurut Ahmad

(2007:198)

motivasi kerja yang dimiliki oleh umat Muslim untuk menghasilkan sebuah karya dan memberikan pelayanan yang prima pada organisasinya tidak hanya berasal dari gagasan pemenuhan kebutuhan diri, peningkatan mobilitas, namun lebih mendasar lagi yaitu meningkatkan standar kehidupan atau pelayanan jasa dari suatu bangsa. Prinsip ini berasal dari keyakinan bahwa sebagai manusia yang memegang amanah di bumi, mereka harus menyadari adanya empat hal berikut:

1. Seseorang giat dalam bekerja karena untuk mencari karunia Allah SWT, sebab Allah SWT telah menurunkan atau memberikan banyak sekali rezeki baik yang berupa sumber daya alam yang dapat di eksplorasi maupun yang membutuhkan proses baru untuk memanfaatkan sumber daya yang tersedia tersebut.

2. Bekerja adalah salah satu perbuatan yang baik (amal salih), yang 
merupakan kunci untuk pencapaian (falah) kesuksesan sejati baik di dunia maupun di akhirat.

3. Bekerja juga berarti beribadah sebagai bentuk ketakwaan kepada Allah SWT, oleh karena itu bekerja haruslah sesuai dengan norma-norma dan nilai-nilai.

4. Pahala atas perbuatan baik tidak sebatas di dunia saja, tetapi akan terbawa hingga ke akhirat nanti, serta hukuman untuk perbuatan buruk juga tidak terbatas pada kehidupan duniawi saja, tetapi juga akan dilaksanakan setelah kematian.

Dengan demikian, dalam berjuang untuk mendapatkan keridhaan Allah SWT dan menghindari murka-Nya, seorang muslim yang bekerja tidak sepenuhnya tergantung pada sistem penghargaan dari organisasi atau masyarakat, secara keseluruhan. Setiap upaya yang dilakukannya termotivasi oleh tujuan mulia, yaitu kesejahteraan di dunia ini, maupun di akhirat.

\section{Usaha Mikro, Kecil dan Menengah}

Sesuai dengan Undang - Undang Nomor 20 Tahun 2008 tentang Usaha Mikro, Kecil dan Menengah (UMKM), pengertian UMKM adalah :

a. Usaha Mikro adalah usaha produktif milik orang perorangan dan/atau badan usaha perorangan yang memenuhi criteria Usaha Mikro sebagaimana diatur dalam Undang-Undang ini. b. Usaha Kecil adalah usaha ekonomi produktif yang berdiri sendiri, yang dilakukan oleh orang perorangan atau badan usaha yang bukan merupakan anak perusahaan atau bukan cabang perusahaan yang dimiliki, dikuasai, atau menjadi bagian baik langsung maupun tidak langsung dari usaha menengah atau usaha besar yang memenuhi kriteria Usaha Kecil sebagaimana dimaksud dalam Undang-Undang ini.

c. Usaha Menengah adalah usaha ekonomi produktif yang berdiri sendiri, yang dilakukan oleh orang perseorangan atau badan usaha yang bukan merupakan anak perusahaan atau cabang perusahaan yang dimiliki, dikuasai, atau menjadi bagian baik langsung maupun tidak langsung dengan Usaha Kecil atau usaha besar dengan jumlah kekayaan bersih atau hasil penjualan tahunan sebagaimana diatur dalam Undang-Undang ini. 
TABEL 2.1

Kriteria UMKM

\begin{tabular}{|c|c|c|}
\hline \multirow{2}{*}{ URAIAN } & \multicolumn{2}{|c|}{ KRITERIA } \\
\cline { 2 - 3 } & ASET & OMZET \\
\hline USAHA & Max 50 Juta & Max 300 \\
MIKRO & & Juta \\
\hline USAHA & $>50$ Juta-500 & $>300$ Juta- \\
KECIL & Juta & $2,5 \mathrm{M}$ \\
\hline USAHA & $>500$ Juta-10 & $>2,5 \mathrm{M}-50 \mathrm{M}$ \\
MENENGAH & $\mathrm{M}$ & \\
\hline
\end{tabular}

Sumber : www.depkop.go.id

\section{METODE PENELITIAN}

Metode dalam penelitian ini menggunakan metode deskriptif kuantitatif. Metode deskriptif adalah metode penelitian yang memusatkan perhatian pada masalah-masalah atau fenomena yang bersifat aktual pada saat penelitian dilakukan, kemudian menggambarkan fakta-fakta tentang masalah yang diselidiki sebagaimana adanya diiringi dengan interpretasi yang rasional dan akurat (Nawawi, 2003). Sedangkan yang dimaksud dengan penelitian kuantitatif adalah penelitian yang menyajikan tahap lebih lanjut dari obeservasi, muncul peranan teknik-teknik statistik seperti distribusi frekuensi, tendensi sentral, dan dispersi (Silalahi, 2009).

\section{Jenis dan Sumber Data}

Data yang digunakan dalam penelitian ini adalah data primer dan data sekunder. Data primer adalah jenis data yang diperoleh secara langsung dari responden penelitian melalui penyebaran kuesioner (daftar pertanyaan), sedangkan data sekunder adalah data yang diperoleh melalui berbagai sumber dan pustaka yang mendukung kebutuhan- kebutuhan penelitian. Data sekunder bisa diperoleh dari dokumentasi perusahaan.

\section{Prosedur Pengumpulan Data}

Populasi adalah wilayah generalisasi yang terdiri atas obyek atau subyek yang mempunyai kualitas dan karakteristik tertentu yang ditetapkan oleh peneliti untuk dipelajari dan kemudian di rangkai kesimpulannya. Populasi dalam penelitian ini adalah karyawan perusahaan UMKM Kulit di LIK (Lingkungan Industri Kecil) Magetan - Jawa Timur yang berjumlah 377 orang. Adapun karakteristik sampel yang digunakan adalah karyawan yang sudah bekerja minimal satu tahun, karena karyawan tersebut sudah mengenal lingkungan kerja dan pemimpinnya.

\section{HASIL DAN PEMBAHASAN}

\section{Gambaran Umum Objek Penelitian}

\section{Profil Lingkungan Industri Kecil Magetan}

Magetan merupakan kabupaten terkecil ke dua se-Jawa Timur setelah Sidoarjo. Kabupaten Magetan didominasi oleh industri kecil atau UMKM yang terdiri dari industri genteng, industri penyamakan kulit dan anyaman bambu. Industri penyamakan kulit merupakan sektor yang cukup andil dalam perindustrian di Kabupaten Magetan. Jumlah penduduk Kabupaten Magetan sebanyak 694.038 jiwa, pertumbuhan penduduk dalam kurun waktu satu tahun adalah 0,10 persen (BPS Magetan: 2013).

Usaha industri kecil dan kerajinan kulit di Magetan telah ada sejak lama. 
Usaha yang pasang surut di alami oleh pengusaha kulit di Magetan sejak zaman Belanda. Pada periode 1950-1960 merupakan masa keemasan dari usaha kulit di Magetan. Sejalan dengan pelestarian industri yang dilakukan oleh pemerintah melalui REPELITA (Rencana Pembangunan Lima Tahun), maka dilakukan pembinaan melalui Kantor Departemen Perindustrian dengan upaya mengembangkan unit-unit usaha dan mengembangkannya.

\section{Pembahasan}

Pengaruh Kepemimpinan Islami Terhadap Motivasi Kerja Islami

Hasil pengujian studi ini menunjukkan bahwa secara parsial variabel kepemimpinan Islami terdapat pengaruh yang signifikan terhadap variabel motivasi kerja Islami. Hasil ini dibuktikan oleh nilai nilai thitung yang diperoleh sebesar 2,051 dimana nilai tersebut lebih besar dari nilai tabel yaitu 1,984. Selain itu dapat dilihat bahwa tingkat signifikan yang diperoleh sebesar 0,043 yang mana nilai signifikan yang diperoleh lebih kecil dari 5\%. Hasil penelitian ini selaras dengan temuan empirik dari penelitian sebelumnya yang dilakukan oleh Maghfiroh (2012); Utami, I. T. (2007); dan Hakim (2012) yang menjelaskan bahwa kepemimpinan Islami berpengaruh terhadap motivasi kerja Islami. Dapat disimpulkan bahwa penerapan kepemimpinan Islami oleh para pengusaha sudah sesuai dengan keyakinan karyawan dan berjalan dengan baik, dapat dinilai sudah optimal dan kepemimpinan yang diterapkan sudah selaras dengan ajaran Islam atau kepemimpinan yang Islami. Seorang pemimpin mempunyai karakter moral yang kuat sehingga bisa mengangkat moral karyawan serta memberikan arahan kepada para karyawan agar dapat meningkatkan motivasi kerja Islami yang akan berhubungan erat dengan kinerja karyawan.

Adanya pengaruh kepemimpinan Islami terhadap motivasi menunjukkan bahwa seorang pemimpin yang dalam menjalankan tugasnya berdasarkan pada syariat Islam akan dapat memberikan dan menciptakan suatu motivasi dari para karyawannya. Pada dasarnya, motivasi kerja Islami merupakan perasaan atau keinginan seseorang yang berada dan bekerja dalam upaya pemenuhan kebutuhan material atau nafkah yang didasarkan pada Al-Qur'an dan Hadits. Pada kondisi tertentu untuk mencapai keinginan dalam kebutuhan material dan berdampak pada kebutuhan pengakuan seseorang (Danim, 2004). Hal tersebut dijelaskan dalam Surat Ar-Ra'd (13:11):

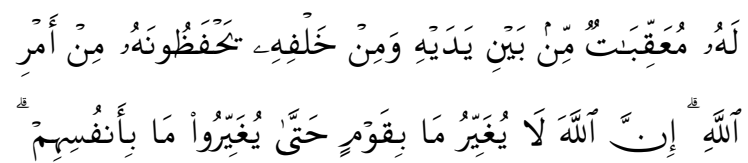

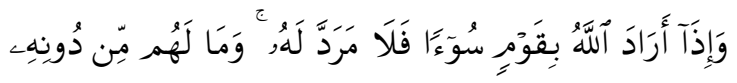
مِن وَالٍ Lahū mu'aqqibātum mim baini yadaihi wa min khalfihī yahfaẓūnahū min amrillāh(i), innallāha lā yugayyiru mā bi qaumin hattā yugayyirū mā bi anfusihim, wa iżā 
arādallāhu bi qaumin sū'an falā maradda lah(ū), wa mā lahum min dūnihĩ miw wāl(in).

Artinya: "Bagi manusia ada malaikatmalaikat yang selalu mengikutinya bergiliran, di muka dan di belakangnya, mereka menjaganya atas perintah Allah. Sesungguhnya Allah tidak merubah keadaan sesuatu kaum sehingga mereka merubah keadaan yang ada pada diri mereka sendiri. Dan apabila Allah menghendaki keburukan terhadap sesuatu kaum, maka tak ada yang dapat menolaknya; dan sekali-kali tak ada pelindung bagi mereka selain Dia." (QS. Ar-Ra'd 13:11)

Firman Allah pada QS. Ar-Ra'd (13:11) diatas apabila diimplementasikan pada karyawan UMKM kulit di Magetan sudah tertanam pada aktifitasnya. Hal tersebut dapat terlihat pada hasil kuesioner yang menunjukkan bahwa nilai motivasi kerja Islami terletak pada setuju. Karyawan UMKM kulit di Magetan berhubungan erat dalam diri mereka yang tertanam pada aktifitas yang dibawa oleh orang terdahulu dalam mengenal Islam dan diterapkan dalam kehidupannya. Oleh sebab itu, kepemimpinan pada pengusaha kulit di Magetan mengikut pada hal-hal yang ditanamkan oleh orang terdahulu yang mana dalam kepemimpinan tersebut masih tercermin kepemimpinan yang Islami.

Peningkatan pengetahuan para pemimpin usaha kulit di Magetan juga diperlukan dalam meningkatkan kompetensi dan pengetahuan yang dimiliki oleh pemimpin. kepemimpinan Islami yang efektif dengan kepribadiannya sebagai orang yang beriman harus menampilkan sikap serta kepribadian yang mengacu pada kepemimpinan yang sudah dilakukan oleh Rasulullah Muhammad SAW yaitu dengan menerapkan sikap yang dimilikinya antara lain shiddiq/kejujuran, amanah/dapat dipercaya, fathonah/pintar, dan tabligh. Seharusnya para pemimpin mempunyai sifat tersebut, agar tercermin didalam pekerjaan yang dilakukan olehnya mengacu pada nilai-nilai Islami. Namun, dalam implementasi setiap pemimpin tidak mudah dalam menerapkan sikap kepemimpinan Islami (nilai-nilai Islami). Sesuai dengan Seperti firman Allah SWT dalam surat QS At-Taubah (9:105):

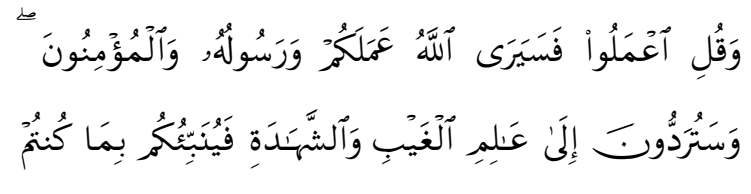
تَعَمَلْونَ Wa quli'malū fa sayarallāhu 'amalakum wa rasūluhū wal mu'minūn(a), wa saturaddūna ilā 'ālimil gaibi wasy syahādati fayunabbi'ukum bimā kuntum ta'malūn(a).

Artinya : "Dan Katakanlah: "Bekerjalah kamu, Maka Allah dan Rasul-Nya serta orang-orang mukmin akan melihat pekerjaanmu itu, dan kamu akan dikembalikan kepada (Allah) yang mengetahui akan yang ghaib dan yang nyata, lalu diberitakan-Nya kepada kamu 
apa yang telah kamu kerjakan." (QS AtTaubah, 9:105).

\section{Pengaruh Budaya Organisasi Islami Terhadap Motivasi Kerja Islami}

Hasil pengujian hipotesis kedua menunjukkan bahwa budaya organisasi Islami memiliki pengaruh yang signifikan terhadap motivasi kerja Islami. Hal tersebut ditunjukkan dengan nilai thitung sebesar 7,325 yang nilainya lebih besar dari tabel sebesar 1,984 dengan tingkat signifikan sebesar 0,000 yang mana nilai signifikan yang diperoleh lebih kecil dari 5\%. Hat tersebut selaras dengan hasil penelitian yang dilakukan oleh Maghfiroh (2012); Hakim (2012); Koesmono, H. T. (2005) yang menunjukkan bahwa budaya organisasi Islami berpengaruh positif terhadap motivasi kerja Islami. Budaya organisasi Islami yang ada pada UMKM kulit di Magetan sudah didasarkan pada nilainilai Islami dan diterapkan pada aktifitasnya. Budaya yang diterapkan dalam banyak interaksi akan memberi pengaruh pada lingkungan sekitar dan akan membentuk suatu budaya baru yang akan seterusnya diterapkan. Budaya organisasi Islam yang diimplemantasikan secara baik dan konsisten akan berpengaruh baik pada pribadi karyawan. Setiap karyawan akan dengan terbiasa menerapkan nilai-nilai Islam dalam aktivitas operasional UMKM. Hal tersebut secara otomatis dapat menumbuhkan motivasi kerja karyawan dalam menjalani tanggung jawab yang telah diberikan. UMKM kulit di Magetan mempunyai budaya kerja Islam yang kuat dengan warisan para terdahulu yang berasaskan Al-Quran dan Sunnah Rasulullah Muhammad SAW, budaya kerja Islam yang diterapkan diantaranya yaitu: ketika adzan dikumandangkan dan masuk waktu sholat, para karyawan melakukan sholat dengan berjamaah, setelah sholat dilakukan karyawan melanjutkan untuk bekerja, karyawan selalu bersikap ramah saat bertemu dengan karyawan lain, dan karyawan bekerja penuh tanggung jawab tanpa diawasi oleh pemimpinnya.

Budaya organisasi Islam yang dilakukan akan menimbulkan nilai Islami di dalam budaya tersebut agar memberikan dasar atau pijakan yang dapat menjadikan bentuk serta cara yang perlu diselenggarakan secara kolektif melalui suatu organisasi, menjadikan seruan atau ajakan kepada seseorang (pemimpin) untuk mengikuti ajaran dan aturan yang ada di dalamnya, seperti firman Allah SWT dalam surat Q.S Ali' Imran (3:110) yang berbunyi;

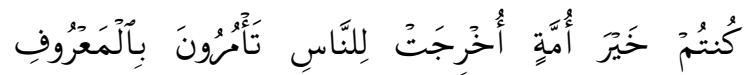

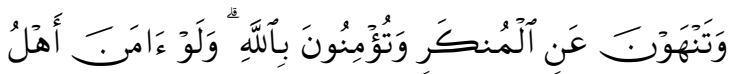

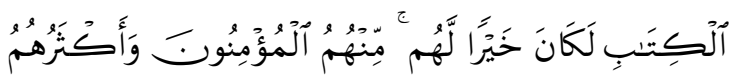
آلَفَسِقُونَ Kuntum khaira ummatin ukhrijat linnāsi ta'murūna bil ma'rūfi wa tanhauna 'anil munkari wa tu'minūna billāh(i), wa lau āmana ahlul kitābi lakāna khairal lahum, minhumul mu'minūna wa akśaruhumul fāsiqūn(a). 
Artinya: "Kamu adalah umat yang terbaik yang dilahirkan untuk manusia, menyuruh kepada yang ma'ruf, dan mencegah dari yang munkar, dan beriman kepada Allah. Sekiranya ahli kitab beriman, tentulah itu lebih baik bagi mereka, di antara mereka ada yang beriman, dan kebanyakan mereka adalah orang-orang yang fasik." (Q.S Ali' Imran 3:110)

Penerapan budaya kerja Islami tersebut dapat dihubungkan dengan hasil penelitian Hakim (2012) yang menujukkan bahwa konsistensi budaya organisasi akan berpengaruh pada aktifitas individu para pegawai agar selalu menerapkan nilainilai budaya pada kehidupannya yang dimulai dari budaya kerja yang sudah tertanam dalam benak dan perilaku karyawan sehingga membentuk sikap yang Islami, baik dalam bekerja ataupun dalam kegiatan sehari-hari seorang karyawan.

\section{Kesimpulan}

Berdasarkan hasil yang telah diperoleh pada bab pembahasan, maka dapat ditarik beberapa kesimpulan sebagai berikut:

1. Hasil pengujian studi ini menunjukkan bahwa variabel kepemimpinan Islami berpengaruh signifikan terhadap variabel motivasi kerja Islami. Penerapan kepemimpinan Islami oleh para pengusaha sudah sesuai dengan keyakinan karyawan dan berjalan dengan baik, dapat dinilai sudah optimal dan kepemimpinan yang diterapkan sudah selaras dengan ajaran Islam.

2. Hasil selanjutnya menunjukkan bahwa budaya organisasi Islami berpengaruh signifikan terhadap motivasi kerja Islami. Hal ini menunjukkan bahwa para UMKM kulit di Magetan sudah menerapkan budaya organisasi Islami yang didasarkan pada Al-Quran dan Sunnah Rasulullah Muhammad SAW dan budaya kerja Islami tersebut diterapkan dalam organisasi sehingga menciptakan motivasi kerja bagi karyawan.

3. Secara simultan kepemimpinan Islami dan budaya organisasi Islami berpengaruh terhadap motivasi kerja Islami. Hal ini menunjukkan bahwa kepemimpinan yang berlandaskan syariat Islam dan budaya yang ada dalam organisasi dapat meningkatkan motivasi kerja karyawan yang ada dalam organisasi sehingga dapat menghasilkan kinerja yang optimal.

\section{DAFTAR PUSTAKA}

Abbassi, R. d. 2009. Propensities of Tajik, Uzbek and Russians Towards Islamic Work Ethics. Journal of Qafqaz University.

Ahmad, Khaliq. 2009. Leadership and Work Motivation from the Cross Cultural Perspective. International Journal of Commerce and Management. volume 19 No. 12009. 
2007. Management From Islamic Perspective: Principle and Practice. Malaysia: Research Centre International Islamic University Malaysia .

.2011. An empirical assessment of Islamic leadership principles. International Journal Commerce and Management. Volume 21 No.3 .

Arep, Ishak dan Hendri Tanjung. 2003. Manajemen Motivasi. Jakarta: PT.Gramedia Widiasarana Indonesia.

Arikunto, Suharsimi. 2004. Prosedur Penelitian Suatu Pendekatan Praktek. Bandung: Rineka Cipta.

Azis, Abdul Wahab. 2008. Anatomi Organisasi dan Kepemimpinan Pendidikan. Bandung: Alfabeta.

Danim, Sudarman. 2004. Motivasi Kepemimpinan dan Efektivitas Kelompok. Jakarta: PT. Rineka Cipta.

Friska. 2004. Kepemimpinan dalam Organisasi. dalam http://digilib.usu.ac.id/ download/fe/manajemenfriska.pdf, diakses tanggal 30 April 2013.

Ghozali, Imam. 2006. Aplikasi Analisis Multivariate dengan Progam SPSS. Semarang: Universitas Diponegoro.

Hakim, Abdul. 2007. Kepemimpinan Islami. Semarang: Unissula Press.
2012. The Implementation of Islamic Leadership and Islamic Organizational Culture and Its Influence on Islamic Working Motivation and Islamic Performance PT. Bank Mu'amalat Indonesia Tbk. Employee in the Central Java. Asia Pacific Management Review17 (1) (2012) 77-90.

Hariandja, Marihot TE. 2002. Manajemen Sumber Daya Manusia. Jakarta: Grasindo

Hasan, Dede. 2002. Kemampuan Manajerial Pimpinan dalam Memotivasi dan Mendisiplinkan Karyawan dikaitkan dengan Produktivitas Kerja. Bandung: PPs UPI.

Kriyantono, Rahmat, 2006, Teknik Praktis Riset Komunikasi, Jakarta: PT Kencana Prenada Media Group.

Koesmono, H. T. 2010. Pengaruh Budaya Organisasi Terhadap Motivasi Dan Kepuasan Kerja Serta Kinerja Karyawan Pada Sub Sektor Industri Pengolahan Kayu Skala Menengah Di Jawa Timur. Ekonomi Manajemen.

Maghfiroh, Siti. 2012. Pengaruh Kepemimpinan Islami dan Motivasi Kerja Terhadap Kinerja Karyawan di Lembaga Keuangan Syari'ah KJKS Kabupaten Kendal (Studi Kasus KJKS di Kecamatan Rowosari dan Weleri). Skripsi. Semarang: 
Institute Agama Islam Negeri Walisongo.

Majeed, Yasir \& Khaliq, Zulqarnain. 2011. The Impact of Islamic Leadership on Organizational Objectives. Far East Journal of Marketing and Management. Volume 1 No.1.

Mulianto, S. 2006. Panduan Lengkap Supervisi Diperkaya Perspektif Syariah. Jakarta: Gramedia Pustaka Utama.

Nawawi. 2003. Metode Penelitian Bidang Sosial. Yogyakarta: Gajah Mada University Press

Omer, Zaneb \& Omar, Syed. 2012. The Effects of Islamic Management Ethics on Organizational Commitment of Employees in Libyan Public Bank. Australian Journal of Basic and Apllied Sciences, 6(7):260-270.

Pramandhika, Ananto. 2011. Motivasi Kerja Islami (Studi Kasus pada Guru TPQ di Kecamatan Semarang Selatan). Jurnal Universitas Diponegoro.

Rizqi, Maudidyah Amalia. 2010. Analisis Model Kepemimpinan Islami Pada CV. Dharma Utama Batu. Malang: UIN Maulana Malik Ibrahim.

Robbins, Stephen P. 2006. Perilaku Organisasi. Jakarta: PT. Indeks Kelompok Gramedia.

Sardiman. 2007. Interaksi dan Motivasi Belajar Mengajar. Jakarta: PT. RajaGrafindo Persada.
Silalahi, Ulber. 2002. Pemahaman Praktis Asas-asas Manajemen. Bandung: Mandar Maju 2009. Metode Penelitian Sosial. Bandung: PT.Refika Aditama.

Singodimedjo, Markum. 2002. Manajemen Sumber Daya Manusia. Surabaya: SMMAS

Sobirin, Achmad. 2007. Budaya Organisasi. Yogyakarta. YKPN.

Sugiyono. 2008. Statistika untuk Penelitian. Bandung: Alfabeta.

Suryati. 2010. Pengaruh Kompensasi Terhadap Motivasi Kerja. Jurnal Mimbar Bumi Bengawan.

Susanto, H., \& Aisiyah, N. 2010. Analisis Pengaruh Kepemimpinan dan Budaya Kerja dengan Motivasi sebagai Variabel Intervening terhadap Kinerja Karyawan di Kantor Pertanahan Kabupaten Kebumen. Magistra No. 74.

Sutrisno, Edy. 2010. Budaya Organisasi. Jakarta: Kencana.

Tasmara, Toto. 2006. Spiritual Centered Leadership-Kepemimpinan Berbasis Spiritual. Jakarta: Gema Insani.

Utami, I. T. 2007. Pengaruh Gaya Kepemimpinan Transformasional Terhadap Motivasi Kerja Karyawan Pada PT Trade Servistama Indonesia-Tangerang. Ekonomi dan Manajemen. 
JESTT Vol. 1 No. 6 Juni 2014

Uyanto, Stainlaus S. 2006. Pedoman

Analisis Data dengan SPSS.

Yogyakarta: Graha llmu.

www.depkop.go.id diakses pada tanggal

21 Juni 2013.

www.immasjid.com diakses tanggal 9 April 2013.

Zahro, Najmatuz. (2005). Pengaruh Gaya Kepemimpinan Terhadap Semangat Kerja Karyawan Pada KUD DAU Malang. Skripsi. Malang: FE. 